\title{
Research On the Mechanism Innovation Of The Cultivation Of Rule Of Law Talents In the View Of Big Data
}

\author{
Yuehong Wu \\ Guangdong University of Technology, Guangzhou, China, \\ The college of political and law \\ julia66886@163.com
}

Keywords: Big data, rule of law talent,training mode ,mechanism innovation

\begin{abstract}
With the rapid development and application of technologies such as cloud computing, internet of things and artificial intelligence, big data has profoundly changed the mode of production, relations of production and living conditions in human society and provided opportunities and opportunities for the development of all walks of life. Expansion capacity. In the era of big data, the rule of law education also needs to make changes to the teaching contents, curricula and teaching methods so as to adapt to the social changes and the demands of the times brought by information technology. The development of big data has brought a series of legal issues, such as information and privacy protection, right to information and public safety. We should consciously use big data to promote the reform and informatization in the area of rule of law, promote the innovation of legal education and personnel training mode, and better promote the shaping of a country ruled by law and a society ruled by law.
\end{abstract}

\section{Introduction}

With the rapid development of information technology, big data has become an important feature of the current informatization development and infiltrated into all aspects of social life. According to the "36th Statistical Report on Internet Development in China" released by China Internet Network Information Center (CNNIC) in July 2015, as of June 2015, the number of Internet users in our country reached 668 million with an Internet penetration rate of 48.8\%. China's domain name The total number reached 22.31 million and the total number of websites reached 3.57 million. According to the related research report, it is estimated that the global data volume will reach 35.2ZB by 2020 . The total amount of data generated in China will exceed $8.5 \mathrm{ZB}$, which is 10 times of 2013's[1].Obviously, in the face of this emerging technology undergoing tremendous change and its accompanying potential social changes, China's education industry is facing unprecedented challenges and opportunities on a routine development track, encountering big data and labor in all aspects The impact brought by intelligence urgently needs to be answered and dealt with in a scientific way to meet the practical needs of practice. However, it is more necessary to conduct a holistic reflection and scientific reconstruction of issues such as promoting self-development and enhancing academic life value. In this sense, in the era of big data, the training model of law education in our country has in fact suffered a tremendous impact and shake, gradually breaking through the current legal education and personnel training quantitative change, is quietly qualitative change, which can not but cause Law Education in China attaches great importance. In order to better respond to the needs of talented people in the era of big data, a number of universities set up their major of "data science and big data technology". In addition to the rise of artificial intelligence in recent years, it is very likely that in the near future, Talent demand poses a greater impact, while big data will play a role in the replacement of some human capital by artificial intelligence. Therefore, it is undoubtedly of practical significance to think about big data for the training of legal persons. Big data will also promote the transformation and upgrading of legal education and personnel training, 
and bring about challenges and impacts on the existing personnel training modes and teaching contents.

\section{Big Data to Promote the Great Changes in the Field of Rule of Law}

The "13th Five-Year Plan" proposal adopted by the Fifth Plenary Session of the 18th CPC Central Committee put forward the strategy of "implementing the national big data strategy and promoting the open sharing of data resources" to elevate the development of big data to an unprecedented strategic height. Big data is becoming a prominent feature of the new era and has had a profound and profound impact on all walks of life. Finding the knowledge and information of state governance and social governance through data mining and research is an important manifestation of the technology and thinking of using big data in social sciences and a new growth point for the development of social science. How to use the information in the area of rule of law and analyze, share and utilize the data to achieve the goal of saving resources, improving efficiency and improving governance are the important areas and contents of the rule of law.Effective use of big data technologies and thinking will be an important resource and driving force for building a country under the rule of law in the new era. It will also be an important way to promote the effectiveness and modernization of state and social governance. If the legal education and law research can not make full use of the technical conditions and development opportunities provided by big data, they can not effectively solve the legal problems and conflict of interests brought about by the development of big data, and can not cultivate the compound legal-typed talents who know both business and technology. Then legal education, research on the rule of law and the legal services industry will therefore lose the dividend for development and legal education can not shoulder the significant historical responsibility entrusted by the rule of law and the rule of law. All in all, big data is not only a technological innovation, but also a tremendous change in the development strategies and business operation modes of all industries and even in people's thinking. The area of the rule of law is no exception.

Technological change is a major driver of talent demand. As information networks evolve from processing data to processing massive amounts of data, the technological revolution brought about by big data will open a major transformation in which human society enters big data and its closely related AI era. The era of big data has completed a series of data-centered technological changes in concepts, technologies and applications. Such extensive and radical changes will inevitably lead to the transformation of mankind's production and communication modes. Social management and structural changes will also Will call for the corresponding changes in the legal system[2].The information technology that big data relies on is changing the mode of production, way of life and way of thinking of mankind, and of course, it is also pushing forward the transformation of personnel training mode and education content. After nearly forty years of hard work, the cultivation of the rule of law talents in our country has formed a relatively mature training program and path. This "mature" training program and path may also become a new obstacle to the reform of personnel training mode in the context of the formation of an outdated "path dependence" inertia. Big data technology and thinking needs to be based on the in-depth combination of mathematics, statistics, computer science and organic integration. These knowledge bases are generally lacking in the current legal professionals training program. In this regard, whether we can make good use of the favorable conditions for "big data" "+" to reform the legal professional teaching model and personnel training programs is a major issue that needs to be deeply thought out and explored in our country.

The development of the rule of law has created space and opportunity for the use of big data technologies and thinking and put forward new requirements on the training of the rule of law personnel. The "Decision" of the Fourth Plenary Session of the 18th CPC Central Committee clearly pointed out that "the innovation of the rule of law personnel training mechanism" poses new and higher requirements for law education in colleges and universities. Legal education in colleges and universities urgently needs to shift from focusing on the expansion of mass scale to the pursuit of quality improvement. Law professional education changes to legal vocational education, devoting efforts to solve such problems as the separation of law education from social needs, the 
mismanagement of production and sales, the structural excess of legal talents, and the lack of high-end professionals. We should vigorously cultivate "law-based beliefs and the rule of law, with a solid legal profession Knowledge, excellent practical skills, elite legal person with erudite humanism and social responsibility "[3].In the past forty years of reform and opening up, China's legislative democracy, open law enforcement and judicial informatization have created the conditions for the use of big data technologies and thinking. The disclosure and disclosure of a large amount of legal information has created the data prerequisite for the informatization construction of the rule of law and also provided the support for the application and development of big data in the legal field. Large amounts of legal data contains a wealth of knowledge and information, which has the inherent relationship and the law needs to be explored. By analyzing and summarizing these legal information and cases, we can find out the problems, causes and countermeasures that are universal. In the current legal professional training programs, there is still a lack of consideration and training of students' ability to analyze data. In other words, in the era of big data, it is necessary for university legal professionals to cultivate the ability to collect and analyze data and to use data to establish models and explore effective ways to provide solutions and solutions to legal problems and to communicate with them Coordination. In general, big data technology poses challenges for current legal professionals and also provides the opportunity and space for the transformation and upgrading of law professions.

The development of information technology and big data has raised many new problems for legal education and legal development and also provided tremendous impetus for the development of the rule of law. How to translate the problems and kinetic energy brought by the development of such big data into the practice and opportunity of training and innovating talents requires in-depth reflection and exploration. For example, an important prerequisite for the development of big data is the collection of data and information. In the process, how to protect the privacy of those who are collected is not only an ethical issue but also a legal issue. There is a need to measure the dynamic balance between big data development and citizen privacy. At the same time, it is also necessary to make systematic trade-offs and compromises between the government's extensive collection of information on citizens, how to effectively serve the public interest and prevent leaks while safeguarding the public's right to know. Without effective legal measures to eliminate the privacy concerns of citizens, the collection of information will encounter various obstacles, soft or hard, thus affecting the authenticity and objectivity of the data itself, thus affecting the credibility of big data. Law research and rule of law professionals need to solve the social problems caused by the development of big data with legal thinking and legal means. Only in this way, the healthy development of big data can be expected, and legal education and personnel training may only be socially recognized and respected.

\section{Big Data Calls for the Rule of Law Personnel Training Mechanism Innovation}

It is the basic orientation of law education and the issue that must be solved first to promote law education reform because it is related to the status and role of law education in the education of the whole country and society. Set up, the specific mechanism for the training of the rule of law personnel and evaluation criteria for the cultivation of the rule of law and other issues. On the morning of May 3, 2017, General Secretary Xi Jinping inspected the China University of Political Science and Law and pointed out: "It is impossible to train qualified personnel in the rule of law and not to develop talents in the area of rule of law and to rule the country in full accordance with the law." How to Build, Perfect, and Maintain From the university to the legal profession, this transmission belt, innovating the rule of law personnel training mechanism, activating the rule of law personnel-driven engine, and sending batches of high-quality composite and applied-type rule of law personnel to the rule of law in China's construction practice are legal talents The requirements of the times for education are the objective needs and wise measures to help the rule of law in China. Any reform that is out of national conditions and ignores social reality will find it difficult to succeed. The reform in law education must be guided by the new requirements that the current law-governing personnel training in governing the 
country in accordance with the law is currently based on. Especially with the rapid development of economic globalization, political multi-polarization, cultural pluralism and information modernization, the reform of legal education not only meets the universal requirements proposed by the ranks of the rule of law of socialism with Chinese characteristics, but also meets the needs of different sectors in society This requires that the legal education reform should be based on the specific requirements of law-governing talents proposed by the law-governing in accordance with the law. Under the guidance of the concept of legal person training in the new era, the all-dimensional design law Education reform path and gradually establish a mode of training qualified persons for the rule of law in line with the requirements of administering the country according to law in an all-round way.In the age of big data, from the perspective of personnel training, legal education needs to be changed in terms of teaching contents, teaching methods and personnel training mode in order to meet the requirements of the quality of qualified personnel in the information age. This is a challenge for the development of law science, Of course, it is also an important opportunity.

First of all, universities and teachers should change their concepts and respond positively. Information technology has long been changing the mode of production, relations of production and modes of education. Big data is also a product of the development of information technology. How to actively integrate the achievements of the development of information technology and big data into law education, enhance the quality of legal personnel training and respond to the needs of social development are major issues that legal education institutions and personnel need to seriously consider. Only legal education institutions and personnel can profoundly understand the significance of big data on legal education, take the initiative to connect, apply the technology and thinking of big data to the formulation of personnel training programs and the updating of teaching contents, and promote the advancement of big data skills and thinking into teaching materials , Into the classroom and into thinking. Big data changes in education and personnel training mode require us to strengthen the training of the rule of law links some of the courses that help to develop big data technologies and thinking, such as strengthening the knowledge and skills of computer science, statistics and mathematics, Fusion. As far as my school and law school are concerned, there is still a great shortage of courses related to big data technology and knowledge. Of course, the relevant teachers are also lacking. Therefore, from the curriculum to teachers equipped, we must improve.

Second, strengthen cooperation in production, study and research to achieve resource sharing. People's congresses, governments, courts, procuratorates and other agencies have many practical resources on legislation, law enforcement and judiciary, as well as first-hand data on the operation of real law, how to effectively use such information and information, and analyze it through big data , Arguably an educational and academic gold mine. In order to achieve mutual benefits and win-win results, it is necessary to strengthen cooperation between these departments and agencies and make use of the research capabilities of universities to work together to develop and utilize these resources of the rule of law. Due to the cost involved in manpower, material and financial resources, it is necessary to strengthen cooperation among different agencies and innovate mechanisms and platforms for coordinated education. The Law Society and the Rule of Law Education Research Association have done a great job of promoting cooperative development and sharing of the data and resources for the rule of law. Only by breaking part of the division and linking up production, study and research can resources be saved better, and the social adaptability of the personnel training of the rule of law can be promoted so that the demand for social development can be met. Without multisectoral concerted efforts and innovative ways of cultivating qualified personnel, relying solely on the existing legal education institutions and teachers' resources can not effectively solve the problem of talent demand for the building of a nation under the rule of law in the era of big data. By scholars behind closed doors, is unable to solve the legal issues of big data. The complexity of the legal issues raised by the development of big data goes beyond the capabilities of legal education institutions and requires concerted efforts from multiple parties to be effectively addressed.

Once again, to create a multi-level all-round rule of law personnel training system. First, it is necessary to improve the mechanism of collaborative education for scientific research institutions and the rule of law departments and set up various platforms. Such as: Strengthening the legal 
responsibility of higher education institutions. To promote the "National Outstanding Law Talents Education and Training Base" approved by the Central Politics and Law Committee and the Ministry of Education as the carrier, to educate and train national-level applied and complex legal professionals, education and training of foreign legal personnel, and education and training of grassroots legal personnel in the western region Multiple platforms. Second, integrate the forces of all parties. Such as: a clear rule of law outside the university education and research institutions and the rule of law practice the responsibility of training departments. Establish the concept of "big talent" and make the connection with the school of law (administration college), social science management department, law society, lawyer association and education of law and order in primary and secondary schools. Introduce party committee, government department, court, procuratorate, law firm and enterprise And other substantive departments to participate in the training of the rule of law personnel, speed up the construction of multi-level, multi-channel teacher building mechanisms and security mechanisms. Third, we must work together to promote the mechanism of educating people, such as: strengthening the law-based substantive departments as an important trainee training responsibilities, the establishment of law students as internships judges, prosecutors assistant and clerk system to support university law teachers to the political and legal organs, Training, depth into law enforcement and judicial practice. Scientificly design a path for the training of personnel under the rule of law in the military and rule by law, train qualified service personnel for the reintegration of the military by law in a targeted manner, and further promote the integration of civilians and civilians through cooperation and interaction.

Finally, reform and innovation, continue to explore effective ways to train qualified personnel of the rule of law. The information age and big data are profoundly changing our lives and education. After 40 years of reform and opening up, the higher education in our country is going to the stage of popularization and the training of legal personnel, which is also at the stage of changing from quantitative change to qualitative change. At present, the development of society is no longer in short supply to the general legal professionals. The compound legal-typed talents who possess modern scientific and cultural knowledge and relevant technologies as well as good professional skills will be competitive growth points in the future. Colleges and relevant education and training institutions should actively adapt to the challenges and needs of the times, reform their personnel training models and teaching contents, incorporate the curriculums of computer science, statistics and big data into the teaching plan in a timely manner, Teaching needs to update the appropriate content in a timely manner, to strengthen the novelty and accuracy of data. Big data science and technology have created a wide range of space for quantitative research and education in the rule of law.

Although in theory schools are the best places to learn and to innovate, from the perspective of our life experience and work experience, because of the high degree of recognition of law professions and the relatively high social status of legal-person professionals, it is possible to make Legal education institutions and legal practice are easily caught in a state of self-satisfaction, but the lack of creative learning ability. This may affect the ability of the legal profession to solve problems and the quality of the training of law-abiding professionals. In the new stage of the new era, the demands of the society for the rule of law personnel are increasing day by day. Our personnel training mode, knowledge storage and dissemination, and teaching methods have not kept pace with the needs of the times. In the information society and big data era, a great deal of new problems have been raised that need to be solved by the legal community and educational institutions. The legitimacy of legal law teachers and the students they train can be solved with legal skills in a timely manner.

\section{Conclusions}

"Governing the country in its entirety in accordance with the law is an important historical task in our country. The vitality of the law lies in its implementation. The effective implementation of the law depends on the training of law-abiding personnel." The training of law-abiding professionals is an important part of governing the country according to law. "Shi Pengpeng:" Reform Legal education personnel training positions in the legal education space "," Legal Expo "2017 the 
twenty-sixth period. China is building a socialist country governed by the rule of law. Social changes in the new era are in urgent need of a breakthrough in the model of training the rule of law personnel and the teaching content. My humble opinion, our legal education, as a whole has not been able to spend much time on the issue of big data, nor how much content to reflect the legal claims and solutions to big data. At a time when information technology and big data are the hallmarks of the great era, without a thorough study of the impact and response of information technology and big data, there is no doubt that we have missed out on one area or opportunity and even missed one responsibility and responsibility. Because of the legal issues brought by big data such as privacy is to be resolved. Big data technologies and thinking create conditions for the reform of legal education and innovation in personnel training. Faced with the new situation and new tasks, as well as the relative surplus of the rule of law personnel training and the new stage of the popularization of higher education, legal education workers need to examine the existing problems and countermeasures of legal personnel training from the dimensions of the existence and development of legal education Perhaps, using the big data technology and thinking of the dividend is an important window of legal education, at least a growth point of a certain room for development!

\section{Acknowledgments}

This paper was supported by the 13th five-year plan of the philosophy and social sciences in guangdong province, "the research on the comprehensive treatment of the practice of the province in the big data era" (No. GD17XFX13), The Chinese postdoctoral science fund program " the procedure control of admission punishment and leniencysystem"(No. 2016M602437)

\section{References}

[1]See Feng Weiguo, Wang Chao: "Research on Anti-Terrorism Information in Big Data Era", Zhang Ling and Liu Ruirong, "Legislative Social Security Prevention and Control System ---- Annual Meeting of China Society of Criminology (2016) China Procuratorial Publishing House 2016 edition. 351-352.

[2]See Yu Zhigang, Li source tablets: "big data changes in the data for the criminal law Institute of sanctions ideas", contained "Chinese Social Sciences" 2014 the tenth period.

[3]Yang Canming: "Rule of Law and Rule of Law Talent Training Mechanism Innovation", contained "Law Education Research" 2016 the first period. 